\title{
Exploring objective climate classification for the Himalayan arc and adjacent regions using gridded data sources
}

\author{
N. Forsythe, S. Blenkinsop, and H. J . Fowler \\ Centre for Earth Systems Engineering Research (CESER), School of Civil Engineering and Geosciences, \\ Newcastle University, Newcastle, UK \\ Correspondence to: N. Forsythe (nathan.forsythe@ncl.ac.uk)
}

Received: 9 September 2014 - Published in Earth Syst. Dynam. Discuss.: 29 September 2014

Revised: 10 March 2015 - Accepted: 9 April 2015 - Published: 28 May 2015

\begin{abstract}
A three-step climate classification was applied to a spatial domain covering the Himalayan arc and adjacent plains regions using input data from four global meteorological reanalyses. Input variables were selected based on an understanding of the climatic drivers of regional water resource variability and crop yields. Principal component analysis (PCA) of those variables and $k$-means clustering on the PCA outputs revealed a reanalysis ensemble consensus for eight macro-climate zones. Spatial statistics of input variables for each zone revealed consistent, distinct climatologies. This climate classification approach has potential for enhancing assessment of climatic influences on water resources and food security as well as for characterising the skill and bias of gridded data sets, both meteorological reanalyses and climate models, for reproducing subregional climatologies. Through their spatial descriptors (area, geographic centroid, elevation mean range), climate classifications also provide metrics, beyond simple changes in individual variables, with which to assess the magnitude of projected climate change. Such sophisticated metrics are of particular interest for regions, including mountainous areas, where natural and anthropogenic systems are expected to be sensitive to incremental climate shifts.
\end{abstract}

\section{Introduction}

The first objective, quantitative systems for global climate classification were developed in the early 20th century by integrating climate data to delineate zones of coherent vegetation type or ecoregion (Belda et al., 2014). By distilling information from multiple climate variables which affect vegetation typology, climatic classifications can provide a framework for understanding natural resource systems (Elguindi et al., 2014). By focusing specifically on climate variables which govern river flows and crop growth, derived climate classifications can also yield insight into the dependency of agricultural production on water resources. However, the bulk of recent literature (e.g. Chen and Chen, 2013; Mahlstein et al., 2013; Zhang and Yan, 2014) is global in scope. In this study we focus for the first time on a specific classification for the Himalayan arc and adjacent regions, concentrating on climate types relevant to the spatial domain and time period of interest.

The Himalayan arc and Tibetan Plateau give rise to river systems which sustain populations numbering in the hundreds of millions (Immerzeel et al., 2010). To derive climate classifications for this region we focus on climate variables which control the hydrological regimes of catchments with mountainous headwaters, and hence with substantial runoff contributions from snow and glacial melt, as well crop yields. Our precise study area encompasses the Indus, Ganges and Brahmaputra basins and is shown in Fig. 1. The topographic contrast is stark between the high-elevation areas of the Himalayan arc and Tibetan Plateau, and adjacent lowlands of the Indo-Gangetic Plain and deserts of Central Asia. Another striking feature of Fig. 1 is the extent of area under irrigation in South Asia. The crops produced by these irrigated surfaces are crucial to the food security of Pakistan, India, Bangladesh and beyond (de Fraiture and Wichelns, 2010). Archer et 


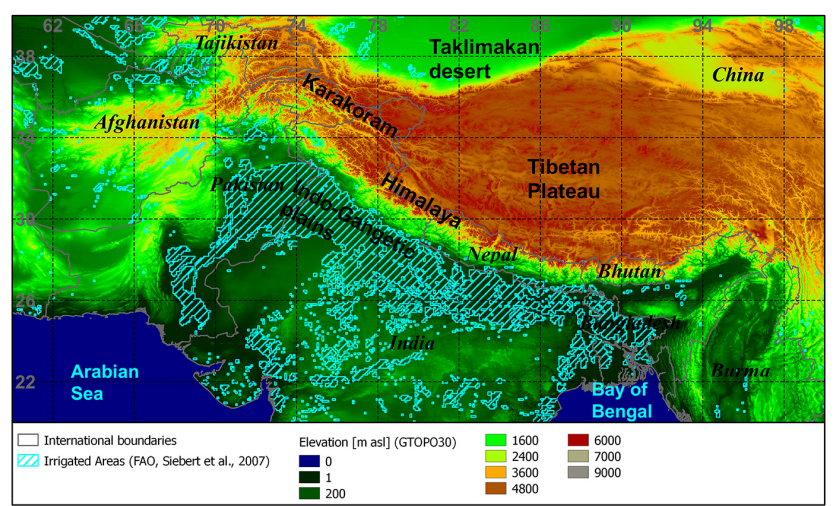

Figure 1. Geographic context of the study area (Himalayan arc and adjacent plains) including elevation and areas with $>33 \%$ under irrigation (hatched). Data sources include the United Nations Food and Agriculture Organization (FAO) and the United States Geological Survey Global 30 Arc-Second Digital Elevation Model (GTOPO30).

al. (2010) point out that the semi-arid plains of the Lower Indus had only marginal (rainfed) agricultural viability until the development of irrigation infrastructure. Irrigation demand in the Lower Indus is supplied by run-off from the Hindu Kush, Karakoram and western Himalaya. Thus holistic understanding of regional food security depends upon characterisation of the spatial as well as climatological differences of these hydrologically connected subregions. Furthermore, it is possible that these subregions will experience distinct trajectories of change in the coming decades. Differential rates, or even signs, of change could substantially alter the regional balance of irrigation water supply and demand. The climate classification approach offers a framework within which to evaluate such water balance scenarios.

Global meteorological reanalyses provide coherent syntheses of atmospheric states including radiative and mass flux exchanges with the sea or land surface. In this paper we compare the climatologies described for the study area from four reanalyses - JRA-55 (Ebita et al., 2011), ERAInterim (Dee et al., 2011), NASA MERRA (Rienecker et al., 2011) and NCEP CFSR (Saha et al., 2011) - which encompass the recent decades rich in data from both ground-based and satellite-borne instruments. In assessing climate classifications derived from each reanalysis we are not only interested in how the climatically defined zones relate to water resource supply (mountainous headwaters) and demand (irrigated plains) areas but also in how the classifications derived from individual reanalyses relate to each other. These intercomparisons establish a methodology for evaluating gridded data sets, including global and regional climate simulations (Elguindi et al., 2014) as well as reanalyses. Comparisons can be made not only between different models but also between different time periods ("time slices"), for either historical data sets (Belda et al., 2014; Chen and Chen, 2013) or simulations by climate models (Mahlstein et al., 2013). Temporal changes in derived climate zones can be assessed in terms of both projected spatial changes (areal extent, elevation range, etc.) and of projected climatic changes (mean, annual range, etc.) in the individual climate variables used to create the classification.

\section{Data and methods}

\subsection{Reanalysis data sets}

Reanalyses are generally conducted by institutions responsible for meteorological forecasting and are undertaken in part to assess the performance forecasting models and the data assimilation systems which support them (Uppala et al., 2005). The resulting coherent multi-decadal syntheses of climate conditions, however, are of substantial utility to a much broader spectrum of natural scientists. In this study we draw upon data from four reanalyses produced by agencies from diverse geographic regions. Characteristics of the reanalyses used in this study are provided in Table 1 and differ in both spatial and temporal resolutions. Given the forecastdriven nature of reanalyses, it is common for time steps to be organised in $6 \mathrm{~h}$ synoptic forecasting time windows. The NASA MERRA data set is distinct in that the default time step is hourly. In all cases daily means were calculated as the mean of the available sub-daily time steps. Daily maximum and minimum were taken as the highest and lowest values respectively amongst the sub-daily time steps unless reported specifically, as was the case for NCEP CFSR. Diurnal range was calculated as maximum minus minimum. In order to make extracted climatic values as comparable as possible, a common reference period, 1980 to 2009, available from each of the reanalyses, was selected for this study. However, comparability of the results was still limited by differing spatial resolutions of the reanalyses as both temperature and precipitation are greatly influenced by topography in mountainous regions (Immerzeel et al., 2012). The fidelity with which each reanalysis reproduces the topography of the study area is limited by its spatial resolution. For this reason, the JRA-55 $\left(1.25 \times 1.25^{\circ}\right.$ resolution $)$ data set is expected to be handicapped compared to the NCEP CFSR $(0.50 \times 0.50$ decimal degree resolution) data set. Nevertheless, other elements, including efficacy of data assimilation and realism of land-surface process algorithms, are also expected to play substantial roles in determining reanalysis skill.

\subsection{Selection of climate variables governing water resources and food security}

The utility of a climate classification depends on the extent to which it reflects the climatic constraints which govern physical processes of interest. If, for example, geochemical processes such as pollutant mobilisation are an overwhelming concern, sensitivity studies can be conducted to identify 
Table 1. Reanalysis data sets utilised for comparative climate classification.

\begin{tabular}{lllcl}
\hline Reanalysis & Producer & Time period covered & Spatial resolution $\left(^{\circ}\right)$ & Diurnal discretisation \\
\hline JRA-55 & JRA & 1958 to (near) present & $1.25 \times 1.25$ & 6h synoptic forecast/analysis periods \\
ERA-Interim & ECMWF & 1979 to (near) present & $0.75 \times 0.75$ & 6 h synoptic forecast/analysis periods \\
CFSR & NCEP & 1979 to 2009 (later extended) & $0.50 \times 0.50$ & 6 h synoptic forecast/analysis periods \\
MERRA & NASA & 1979 to (near) present & $0.67 \times 0.50$ & hourly \\
\hline
\end{tabular}

the key climatic factors involved (e.g. Nolan et al., 2008). In this paper the processes of interest are river flows from mountainous headwaters and agricultural production, both of which depend upon inputs of mass (precipitation) and energy (ambient temperature and incoming radiation). From a simulation standpoint, common approaches for modelling both meltwater generation from seasonal snowpack and glaciers (Ragettli et al., 2013) and crop yields (Baigorria et al., 2007; Kar et al., 2014) require both air temperature and incoming radiation in addition to precipitation as input data. Furthermore, moisture exchanges from the land surface and atmosphere depend upon the latter's vapour pressure deficit, which is commonly expressed as relative humidity. Whilst these parameters can be observed directly, the diurnal temperature range (DTR) also acts as an effective proxy for ambient moisture conditions (Easterling et al., 1997).

In establishing the methodology used here, we favoured reanalysis variables with the simplest relationship to commonly observed parameters at ground-based stations. Hence, $T_{\text {avg }}$ (mean temperature) and DTR - which together describe the diurnal temperature cycle and can be calculated at stations recording solely $T_{\max }$ (maximum temperature) and $T_{\min }$ (minimum temperature) - along with precipitation were selected as governing variables. An exception to this principle was made in selecting net incoming shortwave radiation $\left(\mathrm{SW}_{\text {net }}\right)$ at the ground surface as a governing variable due to the importance of seasonal snow cover in the hydrological regimes of major Himalayan and Tibetan river systems. $\mathrm{SW}_{\text {net }}$ can be observed at standard manned meteorological stations and automatic weather station (AWS) units if they are equipped with radiometers, but is also indirectly available from remote sensing via albedo and cloud climatology. It was largely for the linkage between $\mathrm{SW}_{\text {net }}$ and snow cover via albedo that the former was selected as a key variable. Specifically, land surfaces with full snow cover have a much higher albedo than "bare ground" and albedo evolves during snowpack accumulation and ablation when snow cover is partial. Albedo in turn modulates net shortwave absorption from incoming solar radiation at the surface. Thus net shortwave radiation can serve as a proxy for snow cover. The linkage between $\mathrm{SW}_{\text {net }}$ and cloud cover is also useful, as the latter is an indicator of large-scale weather system - mid-latitude westerly or tropical monsoon - influence. Cloud cover influences $\mathrm{SW}_{\text {net }}$ by modulating the amount of incoming shortwave radiation reaching the surface. In the absence of snow cover, suppression of $\mathrm{SW}_{\text {net }}$ in summer months over South Asia is likely due to monsoonal activity, while suppression in other months suggests mid-latitude westerly disturbances. Table 2 lists the governing variables selected for this study, including the seasonal aggregates of interest, and summarises their physical significance.

Prior to derivation of climate classifications, a comparison of the climatologies from the individual reanalyses provides a context within which differences can be interpreted. To establish a common framework, the "native" resolution data from each reanalysis was regridded (subdivided) to a common $0.25 \times 0.25^{\circ}$ spatial resolution. Ensemble means were calculated, by grid cell, from the simple averages of the four reanalyses. There was no weighting applied from any metric of skill or confidence, nor were any corrections made to account for differences between "native" orography and estimated surface elevation of the target common grid cell. This approach was taken in the absence of detailed information on likely biases by the reanalyses in the variables of interest. Once the ensemble mean had been calculated, normalised differences, i.e. individual reanalysis value minus ensemble mean, were calculated to facilitate comparisons of individual climatologies.

In a study driven by interest in water resources and agricultural production, it is logical to initially focus on precipitation climatologies. Figure 2 shows the ensemble mean reanalysis precipitation climatology and the individual contributions (as normalised differences). In addition to annual totals, seasonal precipitation is differentiated between a cold season (October to March), known regionally as the "rabi", and the monsoon season (April to September), referred to as the "kharif". The regional dominance of monsoonal rainfall is striking when comparing the ensemble means of the seasonal contributions to annual total precipitation, although for the Karakoram/Hindu Kush and north-western Central Asian deserts the rabi precipitation outweighs monsoonal inputs. In comparing the climatologies of the individual reanalyses, the most prominent differences are located along the southern flank of the Himalayan arc and over the Ganges-Brahmaputra Delta along with uplands along the India-Myanmar border region. Broadly, JRA-55 is drier than the other reanalyses along the Nepal-Bhutan-China border but much wetter over the Terai, Assam, the lower Ganges Basin and the Bay of Bengal. NCEP CFSR has similar characteristics, with the exception of being drier over the Bay of Bengal. ERA-Interim 
Table 2. Variables used for Himalayan region climate classification.

\begin{tabular}{lll}
\hline Variable & Season & Physical importance \\
\hline Precipitation & Annual total & Humid vs. arid climates \\
\cline { 2 - 3 } & $\begin{array}{l}\text { ONDJFM } \\
\text { ("rabi") }\end{array}$ & $\begin{array}{l}\text { Westerly (extratropical) weather system climate } \\
\text { influence }\end{array}$ \\
\cline { 2 - 3 } & $\begin{array}{l}\text { AMJJAS } \\
\text { ("kharif") }\end{array}$ & Monsoonal weather system climate influence \\
\hline $\begin{array}{l}\text { avg } \\
\text { daily mean near surface air }\end{array}$ & DJF & $\begin{array}{l}\text { Indicator of precipitation state (solid versus liq- } \\
\text { uid) and available energy to drive hydrological } \\
\text { processes (meltwater generation) and crop growth } \\
\text { (transpiration); as such an indicator of hydrologi- } \\
\text { cal regime (pluvial, nival or glacial) }\end{array}$ \\
\hline $\begin{array}{l}\text { DTR } \\
\text { diurnal temperature range }\end{array}$ & $\begin{array}{l}\text { DJF } \\
\text { MAM }\end{array}$ & $\begin{array}{l}\text { (inverse) Indicator of moisture conditions, i.e. rel- } \\
\text { ative humidity and cloud cover, as both suppress } \\
\text { DTR; as such a proxy for cloud cover further in- } \\
\text { forms regarding circulation influences }\end{array}$ \\
\hline $\begin{array}{l}\text { SW } \\
\text { net downward shortwave } \\
\text { radiation at the surface }\end{array}$ & $\begin{array}{l}\text { DJF } \\
\text { MAM }\end{array}$ & $\begin{array}{l}\text { Indicator of land-surface state (snow-covered or } \\
\text { bare) and available energy to drive hydrological } \\
\text { processes (meltwater generation) and crop growth } \\
\text { (transpiration); as such an indicator of hydrologi- } \\
\text { cal regime (pluvial, nival or glacial) }\end{array}$ \\
\hline
\end{tabular}

and NASA MERRA show the opposite pattern, with ERAInterim being much wetter over the Nepal-Bhutan-China border region and NASA MERRA being much drier over the Terai, Assam and Ganges-Brahmaputra Delta.

While adequate moisture inputs from precipitation are prerequisite for both river flows and agricultural production, the role of energy inputs in both the generation of meltwater runoff, from snow and glacial ice, and driving crop development, through photosynthesis and transpiration, is also critical. Figure 3 shows the ensemble mean climatologies and individual (normalised difference) contributions for winter (December to February) $\mathrm{SW}_{\text {net }}$, spring (March to May) daily $T_{\text {avg }}$ and summer (June to August) DTR. These temporal aggregates (winter, spring and summer) were selected to identify hydrological regimes (pluvial, nival (snowpack) or glacial) and growing seasons dependent upon thermal conditions. As described in Table 2, all three seasonal values (winter, spring, summer) for each of these variables $-T_{\mathrm{avg}}, \mathrm{SW}_{\text {net }}$ and DTR - were used as input to the classification procedure. Figure 3 shows a single seasonal example of each variable to illustrate the information it contributes. Autumn (September to November) seasonal aggregates were not used as they are very similar to spring (mirror image) in terms of magnitude and variability and thus not expected to substantially increase information content available to the PCA.

Figure 3 shows that winter $\mathrm{SW}_{\text {net }}$ illustrates the influence of seasonal snow cover via albedo. As expected there is a generally latitudinal gradient, with decreasing $\mathrm{SW}_{\text {net }}$ moving northward, although the latitudinal gradient is smaller than reductions in net surface absorption in areas with seasonal snow cover. JRA-55 shows generally lower $\mathrm{SW}_{\text {net }}$ values than the ensemble mean, particularly over south-western Pakistan and the Tibetan Plateau. The former difference is likely due to greater reanalysis estimates of cloud radiative effect (CRE), while over Tibet this might be due to either CRE or higher predicted albedo from greater assumed seasonal snow cover. In contrast JRA-55 shows higher $\mathrm{SW}_{\text {net }}$ over the Pamir and sections of the high Karakoram and Himalayan arc. This may be due to either assumed lesser seasonal snow cover (decreased albedo) or estimated clearer sky conditions (decreased CRE). Broadly speaking, ERAInterim and NASA MERRA show the opposite contribution patterns to JRA-55, and hence detailed examination of radiation modulating physical mechanisms, e.g. clear versus overcast conditions and full snow cover versus bare ground, would likely reveal opposing tendencies. Between ERAInterim and NASA MERRA, the former shows broader and more pronounced decreases in $\mathrm{SW}_{\text {net }}$ continuously along the Himalayan arc from Pamir through the east of Bhutan to the Sikkim. NCEP CFSR shows a mixed pattern of $\mathrm{SW}_{\text {net }}$, agreeing with JRA-55 north of approximately $30^{\circ} \mathrm{N}$ and more closely corresponding to ERA-Interim and NASA MERRA south of this line.

The ensemble mean climatology of spring daily $T_{\text {avg }}$ displays the expected influence of elevation, with sub-freezing temperatures found roughly above $3000 \mathrm{~m}$ a.s.l. Like $\mathrm{SW}_{\text {net }}$, $T_{\text {avg }}$ through the freezing isotherm provides a spatial indication of areas with likely snow cover. More generally, $T_{\text {avg }}$ 


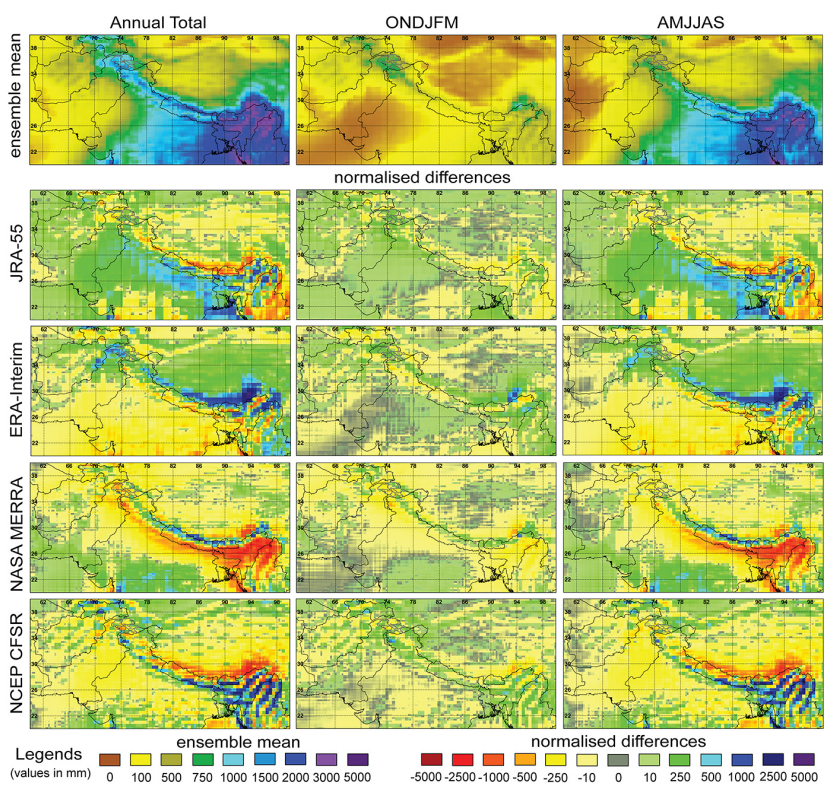

Figure 2. Ensemble precipitation climatology and normalised comparison of individual contributions from reanalyses used in this study. ONDJFM is the abbreviation for the period from October to March, referred to regionally as "rabi". AMJJAS is the abbreviation for the period from April to September, referred to regionally as "kharif".

quantifies the available energy to drive melting of snow and ice as well as plant development. Although NASA MERRA is notably warmer than the other three reanalyses over the Indo-Gangetic Plain, the largest discrepancies are along Himalayan arc as well as at the transition from the Taklimakan Desert to the Tibetan Plateau. JRA-55 and NCEP CFSR are generally colder than the mean along the Himalayan arc but warmer along the northern Tibetan fringe. ERA-Interim is strongly warmer along the Himalayan arc but much cooler over the southern Taklimakan. NASA MERRA has more mixed contributions, with relatively limited areas showing substantial departures from the ensemble mean.

Summer DTR is not a direct indicator of energy input to the hydro-climatological system and biosphere. It does, however, provide a measure of the amplitude of energy variation throughout the diurnal cycle as well as providing a proxy for relative humidity (vapour pressure deficit) and cloud cover. Examination of the ensemble mean summer DTR climatology clearly illustrates the influence of both cloud cover and humidity. Regionally summer DTR is lowest over the Arabian Sea and Bay of Bengal and highest over the western Central Asian deserts. Suppression of summer DTR is clearly evident by comparing the ensemble mean summer DTR in Fig. 3 to the ensemble mean monsoonal precipitation accumulations in Fig. 2. The influence of diurnal discretisation (sub-daily time step) on individual reanalysis DTR climatologies is evident in Fig. 3. NASA MERRA, with an hourly time step, has much larger DTR values over land than the en-

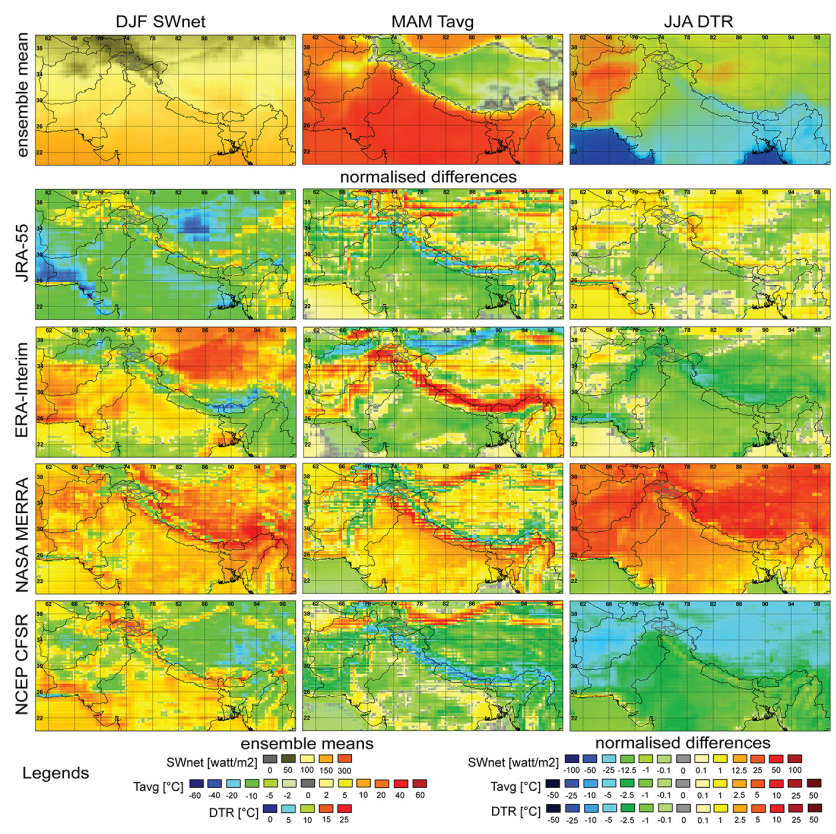

Figure 3. Ensemble energy input (temperature and radiation) climatology and normalised comparison of individual contributions from reanalyses used in this study. $\mathrm{SW}_{\text {net }}$ is net downward shortwave radiation at the surface. $T_{\mathrm{avg}}$ is daily mean near surface air temperature. DTR is diurnal temperature range. DJF is the (winter) period December through to February. MAM is the (spring) period March through to May. JJA is the (summer) period June through to August.

semble mean but lower DTR values than the mean over the Arabian Sea and the Bay of Bengal. MERRA's hourly time step allows better representation of the full amplitude of the DTR, while the $6 \mathrm{~h}$ time steps of the other reanalyses "flatten" or dampen estimated diurnal variations. NCEP CFSR has the lowest DTR values, with particularly small DTR estimates over the Central Asian deserts and Tibetan Plateau. ERA-Interim has broadly, if moderately, lower DTR values than the mean except over the Central Asian deserts as well as the Arabian Sea and Bay of Bengal. JRA-55 is similar to ERA-Interim in DTR estimates, albeit spatially more variable and closer to the ensemble mean.

In summary, the substantial differences, illustrated in Figs. 2 and 3, in input variable climatologies between the individual reanalyses can be attributed to differences in spatial resolution and sub-diurnal discretisation. Reanalyses will also differ in the data assimilation systems and data analysis and forecasting models they incorporate, an exploration of which is beyond the scope of this study. Spatial resolution will have the most pronounced influence in areas with steep topographic gradients and in interface zones between land and sea. Sub-diurnal time -step influence will be limited to absolute accuracy of DTR. While both spatial resolution and sub-diurnal time-step influence absolute accuracy and hence the direct comparability of a reanalysis to other 
data sets, its internal coherence, i.e. relative spatial and temporal variability, may still be substantial. This coherence can be tested through the climate classification process. Where good ground-based observations exist and can be translated meaningfully to the grid cell resolution in the reanalyses, bias assessment could be performed. This would provide insight into which data set more accurately represents regional conditions but would be very challenging and time-consuming due to data paucity and inconsistencies. This in fact highlights one of the major benefits of the climate classification procedure: objective delineation of the regional domain should enable optimisation of the use of limited ground data by defining "areas of relevance" within which the magnitude and distribution of bias can be meaningfully summarised.

\subsection{Method for climate classification}

The climate classification methodology used in this study directly transfers the method developed by Blenkinsop et al. (2008) for the European FOOTPRINT project, albeit with the set of variables described in Sect. 2.2 rather than those identified for FOOTPRINT (Nolan et al., 2008). Blenkinsop et al. (2008) applied a three-step approach to climate zoning: (i) identification of key climatic variables, (ii) principal component analysis (PCA) and (iii) $k$-means cluster analysis. The decision to use the PCA and $k$-means approach, which classifies the spatial domain based on relative differences, rather than to apply a classification based on absolute thresholds, e.g. Köppen-Trewartha (Belda et al., 2014), was made due to the expectation that the spatial aggregation (large grid cells) within the reanalyses would introduce inevitable biases. These biases could be further exacerbated by the formulation of data assimilation and forecasting algorithms adopted by each reanalysis. Thus it seemed more reasonable to apply a relative differentiation rather than an absolute, fixed standard.

As explained by Blenkinsop et al. (2008), PCA is a necessary step in the climate classification process in order to reduce the dimensionality of the input variables, which are expected to be substantially correlated as a set. Prior to PCA all input variables were standardised (subtraction of spatial mean and division by spatial standard deviation). Standardisation was performed so that the unit-dependent absolute values of the individual variables would not distort their weighting within the PCA process. PCA was performed using the "mlab" module of matplotlib (Hunter, 2007) executed in a Python environment. Input and output operations of reanalysis data stored as GeoTiffs were handled using the RasterIO Python module (Holderness, 2011).

The results of the PCA for each reanalysis are summarised in Table 3. A decision was made to retain principal components (PCs) which accounted for at least $5 \%$ of the total variance in the input data set. Table 3 indicates that ERA-Interim and NCEP CFSR each had four PCs which met this criterion while JRA-55 and NASA MERRA had five PCs. Details on

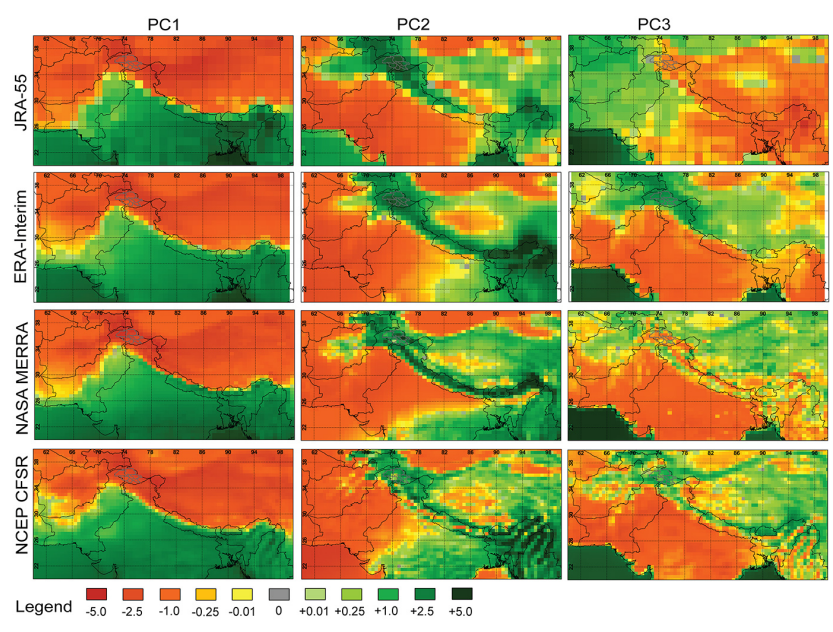

Figure 4. Comparison of the first three principal components (PCs) from each of the reanalyses used in this study. PCs are calculated from the principal component analysis (PCA) input standardised variables using the PCA output weighting factors. PCs are thus dimensionless and values are expressed in standard deviations.

the first three PCs, which together account for between 81 and $85 \%$ of the total variance, for each reanalysis are provided in Table 3, while Fig. 4 shows these PCs graphically. The first PC for all four reanalyses was primarily composed of variables related to energy inputs (daily mean temperature, net shortwave radiation), although JRA-55, ERA-Interim and NASA MERRA all had substantial negative contributions from summer DTR. The first PC accounted for between 36 and $46 \%$ of the total variance depending on the reanalysis chosen. As can be seen in Fig. 4, the differences between the reanalyses in spatial distribution of $\mathrm{PC} 1$ within the domain can be largely accounted for by the respective differences in spatial resolution. Even without allowing for the spatial resolution, differences in the consistency in PC1 between reanalyses are striking.

For the second and third PCs, contributions were very similar between three of the reanalyses (Table 3). For ERAInterim, NASA MERRA and NCEP CFSR, PC2 was dominated by precipitation inputs from all seasons, while negative contributions from summer energy inputs were also present. In these reanalyses PC3 was dominated by DTR, particularly winter and spring. For JRA-55, PC2 was dominated by winter and spring DTR, with a negative contribution from cold season (rabi) precipitation. JRA-55 PC3 was dominated by annual total and monsoonal (kharif) precipitation as well as winter DTR. Despite the differences in composition, i.e. loadings from input variables, spatial variability within the domain for PC2 from JRA-55 is visually very similar to PC2 from the other three reanalyses. In PC2, for JRA55 the Arabian Sea shares the same sign as the Himalayan arc and Ganges-Brahmaputra Delta, while in the other three reanalyses the Arabian Sea has the same sign as the Lower Indus Basin and Central Asian deserts. There are more sub- 
Table 3. Comparison of results of principal component analysis.

\begin{tabular}{|c|c|c|c|c|}
\hline \multicolumn{2}{|c|}{ Gridded data source } & \multirow{2}{*}{$\begin{array}{l}\text { PC1 } \\
\mathbf{0 . 4 5 9}\end{array}$} & \multirow{2}{*}{$\begin{array}{l}\mathrm{PC} 2 \\
\mathbf{0 . 1 9 4}\end{array}$} & \multirow{2}{*}{$\begin{array}{l}\text { PC3 } \\
\mathbf{0 . 1 6 2}\end{array}$} \\
\hline $\begin{array}{l}\text { JRA-55 } \\
5 \text { PCs }>0.05\end{array}$ & $\begin{array}{l}\text { Explained } \\
\text { variance }\end{array}$ & & & \\
\hline & Loading & $\begin{array}{l}\text { JJA DTR }-0.359 \\
\text { DJF } T_{\text {avg }} 0.380 \\
\text { DJF SW }_{\text {net }} 0.384\end{array}$ & $\begin{array}{l}\text { ONDJFM Precip } \\
-0.440 \\
\text { DJF DTR 0.408 } \\
\text { MAM DTR 0.509 }\end{array}$ & $\begin{array}{l}\text { AnnTot Precip }-0.419 \\
\text { AMJJAS PrecipTot }-0.416 \\
\text { DJF DTR }-0.461\end{array}$ \\
\hline \multirow[t]{2}{*}{$\begin{array}{l}\text { ERA-Interim } \\
4 \mathrm{PCs}>0.05\end{array}$} & $\begin{array}{l}\text { Explained } \\
\text { variance }\end{array}$ & 0.364 & 0.317 & 0.167 \\
\hline & Loading & $\begin{array}{l}\text { JJA DTR }-0.353 \\
\text { DJF } T_{\text {avg }} 0.443 \\
\text { MAM } T_{\text {avg }} 0.404 \\
\text { DJF SW } 0.402\end{array}$ & $\begin{array}{l}\text { AnnTot Precip } 0.460 \\
\text { AMJJAS Precip } 0.440 \\
\text { ONDJFM Precip } 0.407 \\
\text { MAM SW }_{\text {net }}-0.353 \\
\text { JJA SW }_{\text {net }}-0.371\end{array}$ & $\begin{array}{l}\text { DJF DTR } 0.622 \\
\text { MAM DTR } 0.621\end{array}$ \\
\hline \multirow[t]{2}{*}{$\begin{array}{l}\text { NASA MERRA } \\
5 \text { PCs }>0.05\end{array}$} & $\begin{array}{l}\text { Explained } \\
\text { variance }\end{array}$ & 0.416 & 0.214 & 0.185 \\
\hline & Loading & $\begin{array}{l}\text { JJA DTR }-0.378 \\
\text { DJF } T_{\text {avg }} 0.404 \\
\text { MAM } T_{\text {avg }} 0.375 \\
\text { DJF SW net } 0.388\end{array}$ & $\begin{array}{l}\text { AnnTot Precip } 0.491 \\
\text { AMMJAS Precip } 0.439 \\
\text { ONDJFM Precip } 0.479 \\
\text { JJA } T_{\text {avg }}-0.395\end{array}$ & $\begin{array}{l}\text { DJF DTR }-0.631 \\
\text { MAM DTR }-0.635\end{array}$ \\
\hline \multirow[t]{2}{*}{$\begin{array}{l}\text { NCEP CFSR } \\
5 \text { PCs }>0.05\end{array}$} & $\begin{array}{l}\text { Explained } \\
\text { variance }\end{array}$ & 0.377 & 0.275 & 0.181 \\
\hline & Loading & 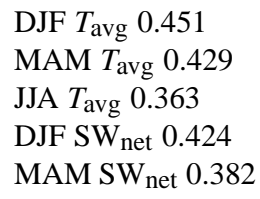 & $\begin{array}{l}\text { AnnTot Precip } 0.459 \\
\text { AMJJAS Precip } 0.440 \\
\text { ONDJFM Precip } 0.367 \\
\text { JJA SW }_{\text {net }}-0.429\end{array}$ & $\begin{array}{l}\text { DJF DTR }-0.478 \\
\text { MAM DTR }-0.645 \\
\text { JJA DTR }-0.462\end{array}$ \\
\hline
\end{tabular}

NB: rows labelled "Explained variance" indicate fraction of total input variance accounted for by the principal component (PC). Rows labelled "Loading" indicate input variables whose (coefficient) contribution to the $\mathrm{PC}$ is $>0.35$. Loading coefficients are shown with their signs to differentiate between variables with opposing contributions.

stantial differences between reanalyses in PC3. In JRA-55 the signs of Central Asian deserts and Tibetan Plateau are reversed compared to the patterns found in $\mathrm{PC} 3$ in the other three reanalyses. For all reanalyses, PC2 accounted for between 19 and $32 \%$ of total variance, while PC 3 accounted for between 16 and $19 \%$. Overall the spatial patterns in Fig. 4 are physically plausible, especially PC1 (mean annual temperature/energy input) and PC2 (annual total precipitation) in the three similar reanalyses (excluding JRA-55). Spatial patterns in PC3 (cold season/rabi DTR) are also physically plausible, although visually they are less intuitive as diurnal temperature cycles are substantial even in high-elevation areas (Karakoram, Himalaya, Tibetan Plateau) in these seasons. They are of lesser amplitude, however, than those experienced currently in the Indo-Gangetic Plain and Central Asian deserts.

$K$-means cluster analysis was also performed using matplotlib (Hunter, 2007) and RasterIO (Holderness, 2011) within a Python environment. As suggested by Blenkinsop et al. (2008), standardised grid cell latitude and longitude were added to the retained principal components as input to the clustering process. Because $k$-means cluster analysis presupposes the number of distinct (climate) classes rather than determining the number groupings (zones) based on a numerical measure of "likeness", a range of cluster numbers was tested for each reanalysis. The results are presented in the following section, but the our interpretation was that the study domain could be aptly described by eight subregional climate zones with increases in cluster numbers leading to subdivisions of these zones. The issue of spatial discretisation of steep topographic gradients, and hence temperature and precipitation gradients, in the transition zone between the (southern flank of the) Himalayan arc and Indo-Gangetic Plain does, however, raise a legitimate caveat to this generalisation. 
Table 4. Description of primary Himalayan region climate zones (eight clusters).

\begin{tabular}{|c|c|c|c|c|c|c|}
\hline \multirow{2}{*}{$\begin{array}{l}\text { Regional climate } \\
\text { zone name/area }\end{array}$} & \multirow[t]{2}{*}{ Climate type } & \multirow[t]{2}{*}{ Characteristics } & \multicolumn{4}{|c|}{ Fraction of domain covered } \\
\hline & & & JRA-55 & $\begin{array}{l}\text { ERA- } \\
\text { Interim }\end{array}$ & $\begin{array}{r}\text { NASA } \\
\text { MERRA }\end{array}$ & $\begin{array}{l}\text { NCEP } \\
\text { CFSR }\end{array}$ \\
\hline $\begin{array}{l}\text { Arabian Sea and } \\
\text { Bay of Bengal }\end{array}$ & Subtropical ocean & $\begin{array}{l}\text { Year-round warm temperatures, minimal } \\
\text { DTR, limited monsoonal precipitation }\end{array}$ & 0.069 & 0.077 & 0.066 & 0.080 \\
\hline $\begin{array}{l}\text { Central Asian } \\
\text { deserts }\end{array}$ & Mid-latitude desert & $\begin{array}{l}\text { Cold winter, hot summer, minimal annual } \\
\text { precipitation }\end{array}$ & $0.199 *$ & 0.150 & 0.168 & 0.101 \\
\hline Tibetan Plateau & $\begin{array}{l}\text { High-elevation } \\
\text { desert }\end{array}$ & $\begin{array}{l}\text { Cold winter, mild summer, limited mon- } \\
\text { soonal precipitation }\end{array}$ & 0.229 & 0.207 & $0.266^{*}$ & 0.227 \\
\hline Himalayan arc & $\begin{array}{l}\text { Subtropical high } \\
\text { mountains }\end{array}$ & $\begin{array}{l}\text { Cold winter, mild summer, substantial mon- } \\
\text { soonal precipitation weather }\end{array}$ & $* *$ & 0.061 & $* *$ & 0.039 \\
\hline $\begin{array}{l}\text { Karakoram/Hindu } \\
\text { Kush }\end{array}$ & $\begin{array}{l}\text { Mid-latitude high } \\
\text { mountains }\end{array}$ & $\begin{array}{l}\text { Cold winter, mild summer, substantial pre- } \\
\text { cipitation from westerly weather systems } \\
\text { (winter and spring) }\end{array}$ & 0.058 & 0.064 & 0.050 & 0.064 \\
\hline Lower Indus Basin & Semi-arid plains & $\begin{array}{l}\text { Mild winter (cold season), hot summer, lim- } \\
\text { ited monsoonal precipitation }\end{array}$ & 0.133 & 0.152 & 0.179 & 0.194 \\
\hline Gangetic plains & Sub-humid plains & $\begin{array}{l}\text { Mild winter (cold season), hot summer, sub- } \\
\text { stantial monsoonal precipitation }\end{array}$ & 0.217 & 0.192 & 0.163 & 0.222 \\
\hline $\begin{array}{l}\text { Ganges- } \\
\text { Brahmaputra } \\
\text { Delta }\end{array}$ & Humid plains & $\begin{array}{l}\text { Mild winter (cold season), warm summer, in- } \\
\text { tense monsoonal precipitation }\end{array}$ & 0.090 & 0.093 & 0.104 & 0.069 \\
\hline
\end{tabular}

*Combination of two climate zones in this reanalysis. **Not identified by this reanalysis.

\section{Results}

\subsection{Description of emergent regional climate zones and subdivisions}

Figure 5 shows the results of $k$-means clustering for each reanalysis for 8, 12 and 16 clusters. Similar subdivisions of the eight subregional climate zones tend to emerge in all the reanalyses as cluster numbers increase, although subdivisions first emerge dependent upon spatial discretisation and climatological differences - illustrated in Figs. 2 and 3 - of each reanalysis.

The general characteristics of the eight emergent subregional climate zones are described Table 4 along with the fraction of the spatial domain each covers in each reanalysis (for the eight-cluster case). With the exception of the Himalayan arc zone, which was not identified by both JRA55 and NASA-MERRA when the number of clusters was limited to eight, there is substantial agreement not only on the broad geographic locations of the eight zones but also on their spatial extent within the domain. There is arguably some blurring in the definition of the "Lower Indus Basin" (semi-arid plains), which regionally could be seen as a transitional zone between the "Central Asian deserts" and the "Gangetic plains" (sub-humid plains), although the latter could itself be seen as a transitional zone between the Lower Indus and the "Ganges-Brahmaputra Delta" (humid plains).

\subsection{Comparison of climatologies of emergent subregional climate zones}

The spatial mean and ranges (minimum and maximum) have been calculated for the period monthly means of the four input variables from each reanalysis. The annual cycles of precipitation and DTR are shown in Fig. 6. The annual cycles of daily mean temperature and net shortwave radiation are shown in Fig. 7. Placement of subregional zones within these figures are deliberate in their relationship to geographical location and large-scale circulation influences. The most northerly zones are in the upper figure panels, and the most southerly at the bottom. Zones with greater westerly weather system influence are in the left-hand column, while greater monsoonal influence zones are to the right. Results shown in both figures are referred to in the discussion throughout this section.

\subsubsection{Precipitation climatologies of emergent subregional climate zones}

Precipitation is a core element in differentiating the eight emergent subregional climate zones within the study domain. The Ganges-Brahmaputra Delta (humid plains) has by far the highest precipitation of the subregional zones followed by the Gangetic plains (sub-humid plains) and the Himalayan arc. Precipitation in each of these zones is dominated by monsoonal rainfall although the Himalayan arc re- 


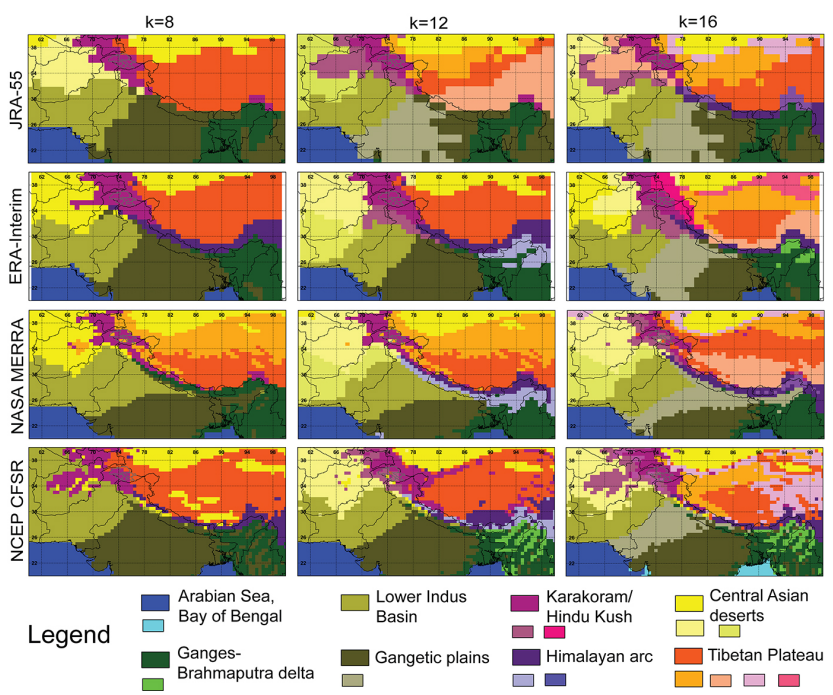

Figure 5. Comparison of climate classifications resulting from the use of 8,12 and 16 clusters $(k)$ on principal components from the individual reanalyses. Large units in the legend refer to zones for the $k=8$ case.

ceives moderate precipitation from westerly weather systems in late winter (February) and spring. The Karakoram/Hindu Kush zone is the next wettest with dominant inputs from rabi westerly weather systems and limited summer rainfall. The Tibetan Plateau has a similar seasonal distribution of precipitation to the Himalayan arc but with lower monthly totals. The Lower Indus Basin and Central Asian deserts are the driest zones. Spread in spatial means between reanalyses is substantial for all climate zones and appears roughly proportional to precipitation amount, i.e. the largest spread is found in the wettest months and in the wettest zone (GangesBrahmaputra Delta).

\subsubsection{DTR climatologies of emergent subregional climate zones}

As explained in Sect. 2.2, ensemble spread in DTR climatologies can be substantially attributed to issues of subdiurnal discretisation. For all climate zones except the Arabian Sea and Bay of Bengal, the reanalysis with an hourly time step (NASA MERRA) has the largest DTR values. Despite similar sub-diurnal discretisation, NCEP CFSR has consistently lower DTR values across all climate zones than ERA-Interim and JRA-55, which tend to agree closely with one another. Despite this considerable ensemble spread in absolute values, the "shape" of annual DTR cycles within climate zones is consistent between reanalyses, i.e. standardised values are very similar. Zones with substantial monsoonal influence - the Ganges-Brahmaputra Delta, Gangetic plains and Himalayan arc - have annual DTR minima in summer. In contrast, drier and more westerly dominated subregional zones - the Central Asian deserts, Tibetan Plateau,
Karakoram/Hindu Kush and Lower Indus Basin - have annual DTR minima in winter, although the Lower Indus has a sufficient monsoonal influence for a minor minimum (limited DTR suppression) in summer. The Arabian Sea and Bay of Bengal have the smallest DTR values both in absolute terms (annual mean) and amplitude of annual cycle.

\subsubsection{Daily mean temperature climatologies of emergent subregional climate zones}

Based on the PCA results presented in Sect. 2.3, differences in energy inputs account for the largest fraction of variance within the input data. Differences in annual cycles of daily $T_{\text {avg }}$ provide clear differences between the emergent subregional climate zones. The Arabian Sea and Bay of Bengal have year-round moderately warm temperatures with minimal spread in both ensemble mean and in spatial spread within individual reanalyses. The GangesBrahmaputra Delta has similar monthly spatial mean values to the Arabian Sea but with incrementally larger ensemble spread and much greater spatial spread. The spatial spread is attributed to the topographic diversity within the zone, stretching from coastal areas to the front ranges of the Himalaya. The Lower Indus Basin and Gangetic plains have quite similar annual cycles of daily mean temperature. Both have mild cold seasons (rabi) and hot summers with large spatial spreads in all months. The ensemble spread is incrementally larger in all months for the Lower Indus than for the Gangetic plains. The remaining four zones - the Central Asian deserts, Tibetan Plateau, Karakoram/Hindu Kush and Himalayan arc - are alike in several months of the annual cycle, with mean temperatures below freezing. Ensemble and spatial spreads are greater in the Central Asian deserts and Karakoram/Hindu Kush than in the Tibetan Plateau, which is consistently the coolest zone. For the Himalayan arc, ERAInterim and NCEP CFSR agree closely for both the spatial means and the considerable spatial spreads of this zone.

\subsubsection{Net shortwave radiation climatologies of emergent subregional climate zones}

Net shortwave radiation at the surface is, understandably, the least differentiated of the input variables. Of interest is the varying degrees of $\mathrm{SW}_{\text {net }}$ suppression in different seasons. In cold months shortwave suppression is due to increased albedo from seasonal snow cover and to a lesser extent to CRE from thick cloud cover. This is evident in the Tibetan Plateau and Karakoram/Hindu Kush, where the annual minima is well below $100 \mathrm{~W} / \mathrm{m}^{2}$. Sub- $100 \mathrm{~W} / \mathrm{m}^{2}$ annual minima in the Central Asian deserts are more surprising and may in part be due to airborne dust particles. Higher winter $\mathrm{SW}_{\text {net }}$ for the Himalayan arc, comparable to the Lower Indus, than the Karakoram/Hindu Kush may be attributable to the lower latitude and lesser seasonal snow cover of the more easterly mountain range. Summer $\mathrm{SW}_{\text {net }}$ suppression will be caused 


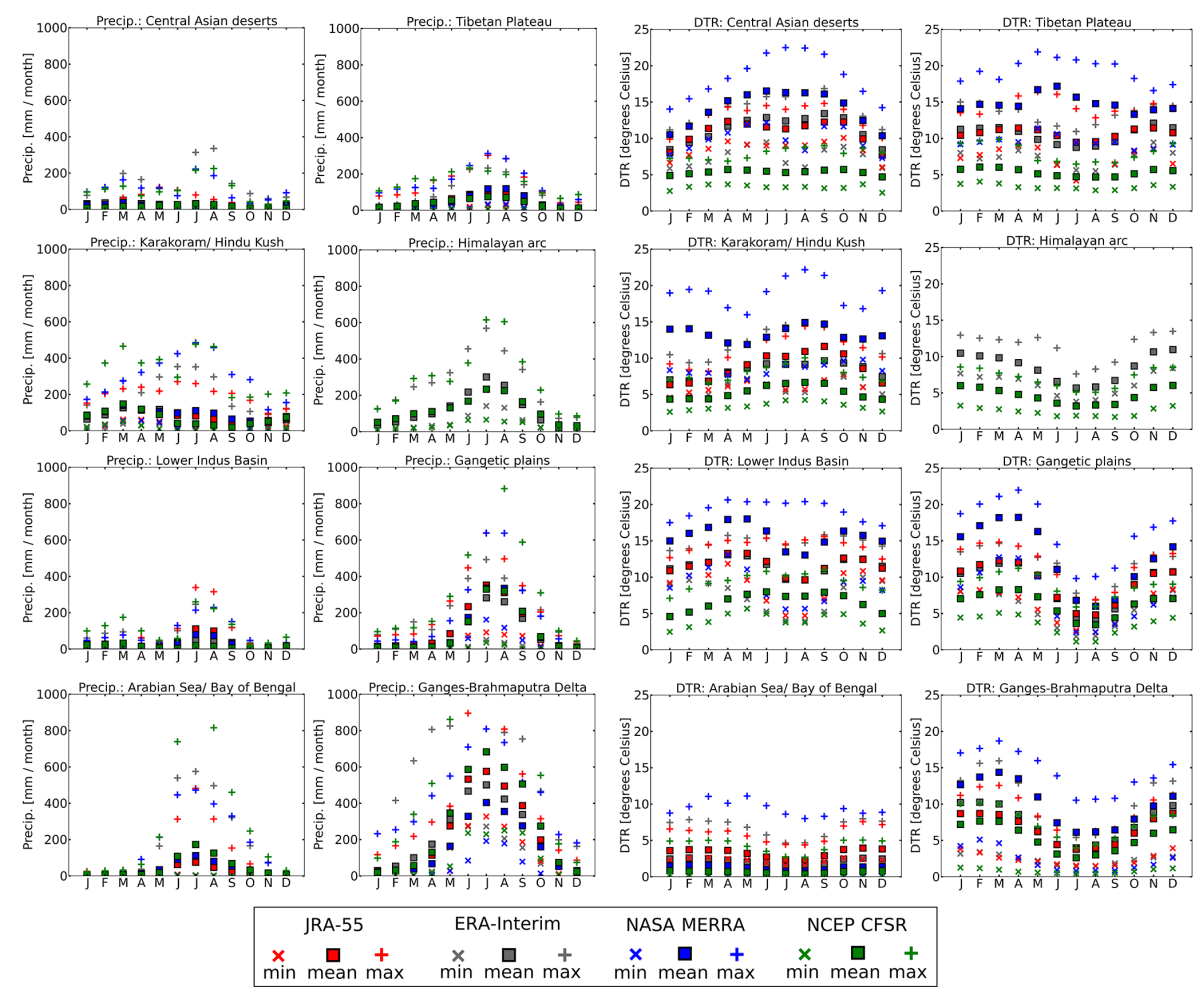

Figure 6. Ensemble spatial statistics for annual cycles of precipitation (left) and DTR (right) by climate zone (eight clusters). DTR is diurnal temperature range.

by large CRE linked to monsoonal activity. This is particularly visible in the Ganges-Brahmaputra Delta and Gangetic plains and still noticeable in the Himalayan arc and Arabian Sea. The effect is present, though barely perceptible, in the Lower Indus Basin.

\subsubsection{Commonalities and distinctions in the climatologies of emergent subregional climate zones}

The layout of Figs. 6 and 7 is intended to facilitate comparison of adjacent climate zones. Climate zones are represented within Figs. 6 and 7 moving from north to south by moving from top to bottom panels. Given the latitudinal influence on temperature, zones with similar temperature regimes, e.g. the Lower Indus Basin and Gangetic plains, are laterally adjacent. In contrast, the dependence of precipitation on atmospheric circulation can be examined by comparing these adjacent panels. Thus the Lower Indus Basin, with limited monsoonal rainfall, is found by the clustering process to be distinct from the Gangetic plains. Similarly the Tibetan Plateau is distinguished from the Central Asian deserts not only by cooler temperatures but also by greater monsoonal precipitation. The Karakoram/Hindu Kush and Himalayan arc have similar temperature regimes, but the seasonality and magnitude of annual precipitation, driven by the differing circulation influences, clearly separates them. Even without knowl- edge of land or sea presence, the Ganges-Brahmaputra Delta zone is distinct from the Arabian Sea zone by both precipitation and DTR.

\section{Discussion}

\subsection{Insights from climate classifications for water resources and food security in South Asia}

The PCA and $k$-means clustering approach applied to climate classification for the Himalayan arc and adjacent regions, focusing on water resources and food security, has found a consensus among four global meteorological reanalyses to identify eight emergent subregional climate zones. These zones are physically plausible and correspond to broadly recognised units of vegetation typology and land-surface characteristics in South and Central Asia. Of these eight zones, one is open water (the Arabian Sea and Bay of Bengal), while two - Central Asian deserts and the Tibetan Plateau - are sparsely populated. The three plains zones - the Lower Indus Basin, Gangetic plains and Ganges-Brahmaputra Delta - are densely populated and projected to experience rapid demographic growth in the coming decades (Archer et al., 2010; Immerzeel and Bierkens, 2012). In addition to direct precipitation assessed in the climate classification, these plains regions receive river flows from upstream areas: the Karakoram/Hindu Kush is upstream of the Lower Indus Basin, while 

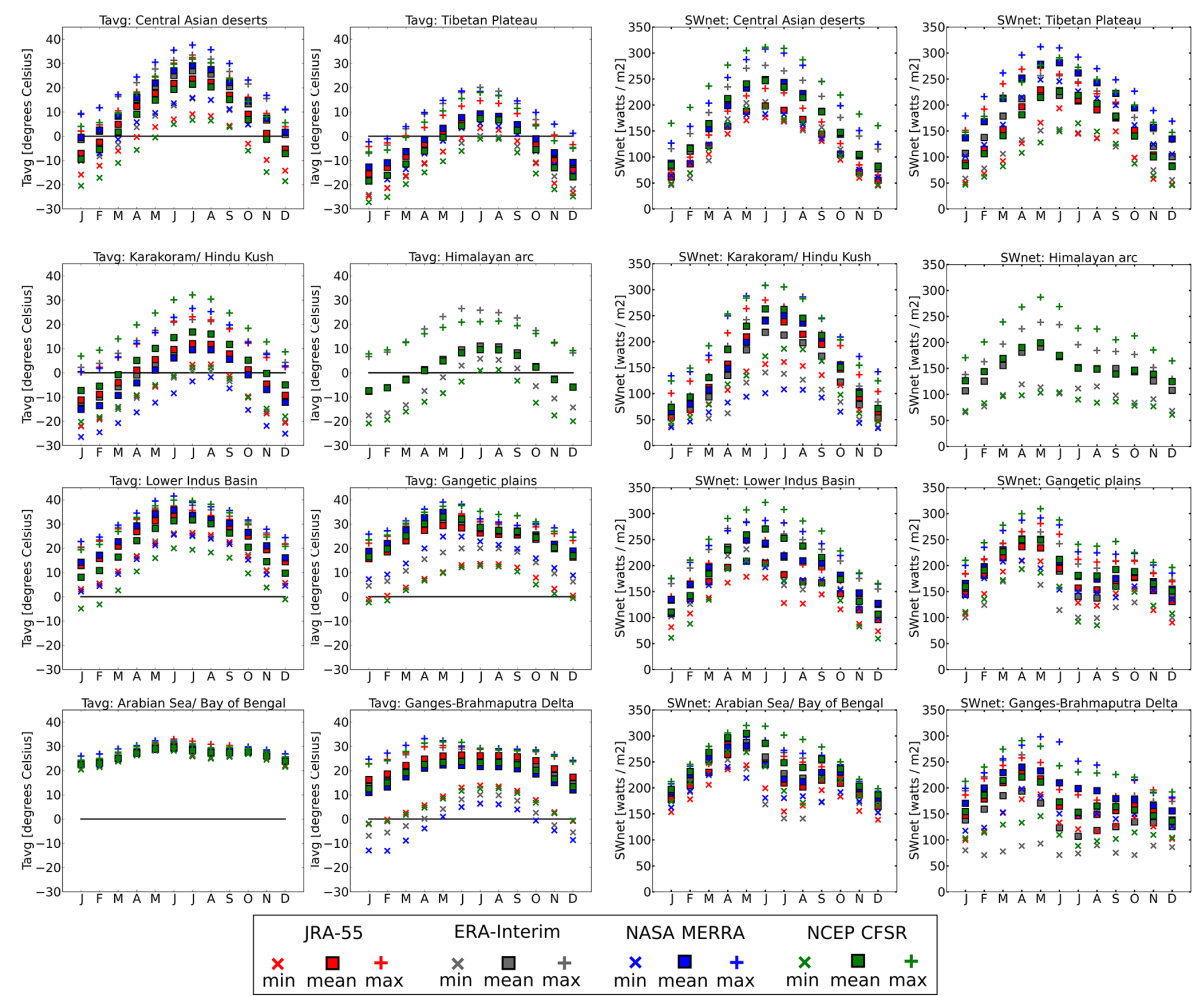

Figure 7. Ensemble spatial statistics for annual cycles of $T_{\text {avg }}$ and $\mathrm{SW}_{\text {net }}$ by climate zone (eight clusters). $\mathrm{SW}_{\text {net }}$ is net downward shortwave radiation at the surface. $T_{\text {avg }}$ is daily mean near surface air temperature.

the Himalayan arc is upstream of the Gangetic plains and Ganges-Brahmaputra Delta. The precipitation climatologies of individual climate zones presented in Fig. 6 confirm that the Lower Indus Basin receives substantially less direct precipitation than the other two plains climate zones. In a firstorder analysis, irrigated areas in the Lower Indus, shown in Fig. 1, are thus much more dependent upon upstream flows than their Gangetic counterparts.

This general assessment does not, however, take into account the question of intra-annual (inter-seasonal) water transfers, as the annual cycle of Ganges Basin tributary river flows will closely follow the annual precipitation cycle. Thus, in the absence of impounding reservoirs or substantial groundwater recharge, only limited water volumes would be available to supplement irrigation in the dry rabi season. This study also does not take into account inter-annual variability, as the climate classifications here draw solely upon period means (1980 to 2009). A further limitation of this assessment is that at the "parcel scale" of rainfed agriculture the convective precipitation in monsoonal weather systems has very large spatial variability (Khan et al., 2014). Thus, while farmers in the irrigated Lower Indus Basin rely upon upstream flows for the bulk of crop moisture requirements, farmers in the Gangetic plains may find supplementary irrigation critical to compensate for spatially and temporally acute precipitation deficits and ensure crop yields.
Looking forward, climate classifications of the type applied in this study help to frame the assessment of the impact of changing climate conditions on future water resources, crop production and food security. By understanding the roles of subregional climate zones as water resource supply (headwaters) and demand (irrigated plains) areas, the net result of changes in water availability (precipitation change) and potential evapotranspiration (air temperature, shortwave radiation and relative humidity change) can be more skilfully evaluated. Changes, calculated between time slices of dynamically downscaled climate model simulations, in both the spatial extent and climatological statistics of water resource supply and demand zones in and of themselves provide information on the trajectory of water availability, i.e. unit yield or deficit multiplied by surface area. Additionally, delineation of subregional climate zones provides an objective basis for definition of study boundaries of more sophisticated nested downscaling investigations. Accurate delineation is important when computational requirements are high, for example when high-resolution sensitivity experiments are required to constrain the uncertainties in future supply and demand scenarios. 


\subsection{Utility of climate classification for assessment of gridded data sets}

The ensemble reanalysis input climatologies and normalised difference contributions shown in Figs. 2 and 3 illustrate the initial steps in comparative assessment of gridded data sets for bias characterisation and validation. Further logical steps would draw upon the climate zones derived through the PCA and $k$-means clustering approach to subdivide the spatial domain in order to focus and organise the use of limited in situ data (ground-based, point observations) to characterise subregional data set performance. The use of in situ data to provide "ground truthing" and related large-scale data sets to local conditions will remain crucial for the foreseeable future because gridded data sets of a global nature - be they reanalyses, spatially interpolated from local observations, or derived from satellite imagery - will inevitably have intrinsic biases. These biases are a function of spatial and temporal resolution of the source observations as well as the physical nature of those observations. In situ data, be they from national monitoring networks or international databases such as the Global Historical Climatology Network (Lawrimore et al., 2011), could be grouped by the derived climate zones and in this way structure the analysis of statistics of "grid cell versus station" biases. In this way individual gridded data sets could be assessed to determine in which subregional climate zones they perform well or poorly. This approach also permits comparative evaluation of different gridded data sets to determine which most accurately reproduces the climatology of a given climate zone.

This proposed methodology for bias assessment is dependent, however, upon the availability of station data, which are representative of climatic conditions in absolute terms at the grid-scale level. This constraint could be prohibitive for mountainous areas, such as the Karakoram/Hindu Kush, where meteorological stations are often located in valley bottoms, substantially below the mean elevations of overlying data source grid cells. One such example is the Upper Indus Basin (Gilgit-Baltistan administrative district of Pakistan), where Archer $(2003,2004)$ and Archer and Fowler (2004, 2008) found climate observations at manned meteorological stations of the Pakistan Meteorological Department located in valley settlements to correlate strongly with variability in hydrological conditions, although runoff volume fluctuations did not equate directly to precipitation anomalies. Thus, in mountainous or other highly spatially variable domains, "transfer functions" (scaling relationships) representing climate parameter variation with topography may still be necessary to compare in situ point observations to grid cell spatial means in absolute terms.

These challenges for relating point-based observations to gridded data in fact point toward the utility of intercomparison of spatial data sets. The climate classification approach provides a supplementary dimension in which to compare gridded data sets. To illustrate this, the subregional

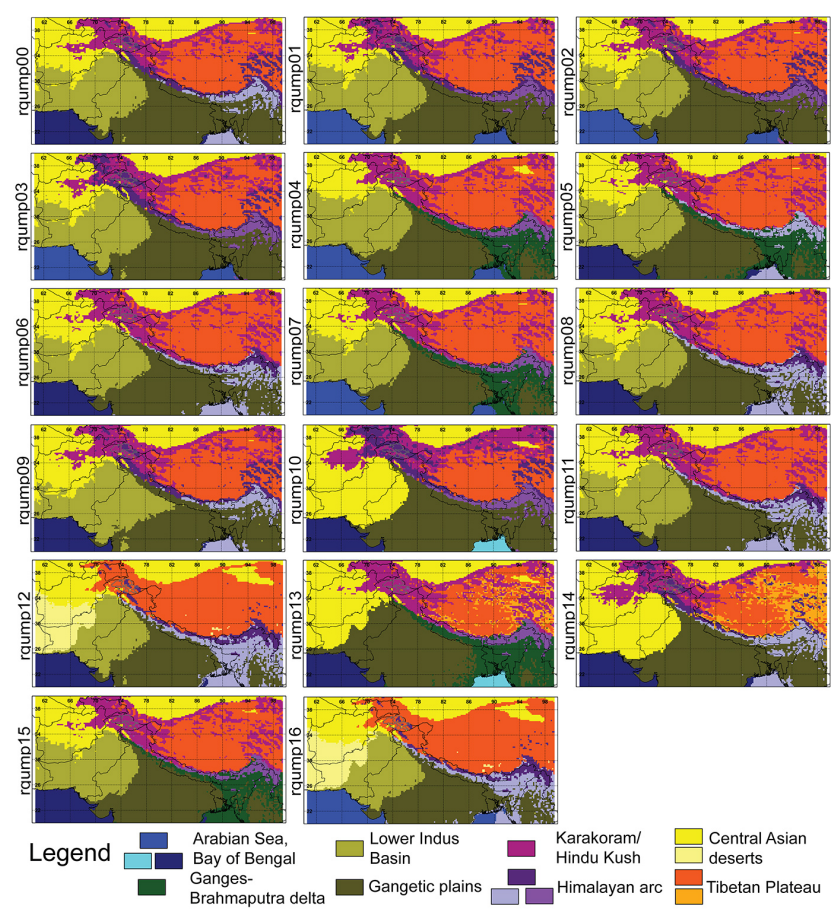

Figure 8. Comparison of climate classifications resulting from the use of eight clusters on principal components of the control period (1970 to 1999) from the individual members of the Hadley Centre RQUMP perturbed physics ensemble downscaled over South Asia.

climate zones delineated from the four reanalyses could be considered as reference or benchmark values for evaluation of climate model control period outputs. Ongoing work is exploring the application of the climate classification approach to time slices within the Met Office Hadley Centre 17-member perturbed physics ensemble of 130-year transient future climate simulations (Collins et al., 2011) dynamically downscaled to $0.22^{\circ}$ for the South Asia domain (Bhaskaran et al., 2012). Climate classifications, using eight clusters, for the initial 30 years (1970 to 1999) of the simulation, considered as the "control climate", are shown for each of the ensemble members in Fig. 8. Visual comparison of Fig. 8 to Fig. 5 confirms that the broad patterns of the subregional climate zones found by the reanalyses are replicated in the control climate time slice of the climate model ensemble. There are noteworthy differences, particularly over the GangesBrahmaputra Delta, but the overall subregional differences are unmistakeable. Table 5 provides the distribution of the spatial domain among the subregional climate zones for each climate model ensemble member. The ensemble mean and standard deviation are also given in Table 5. These values are compared, in Table 6, to the equivalent values from the reanalyses (from Table 4). The largest differences in fractional areas stem from an eastern Himalayan climate zone in the model ensemble amalgamating area allocated to the GangesBrahmaputra in the reanalyses as well as sections assigned 
Table 5. Variability in primary Himalayan region climate zones (eight clusters) in the Hadley Centre downscaled perturbed physics ensemble, Regionally Quantify Uncertainty in Model Predictions (RQUMP), for South Asia.

\begin{tabular}{|c|c|c|c|c|c|c|c|c|}
\hline $\begin{array}{l}\text { Ensemble } \\
\text { member }\end{array}$ & $\begin{array}{l}\text { Indian } \\
\text { Ocean }\end{array}$ & $\begin{array}{r}\text { Central } \\
\text { Asian } \\
\text { deserts }\end{array}$ & $\begin{array}{r}\text { Gangetic } \\
\text { plains }\end{array}$ & $\begin{array}{r}\text { Lower } \\
\text { Indus } \\
\text { Basin }\end{array}$ & $\begin{array}{r}\text { Karakoram/ } \\
\text { Hindu } \\
\text { Kush }\end{array}$ & $\begin{array}{r}\text { Himalayan } \\
\text { arc }\end{array}$ & $\begin{array}{r}\text { Ganges- } \\
\text { Brahmaputra } \\
\text { Delta }\end{array}$ & $\begin{array}{l}\text { Tibetan } \\
\text { Plateau }\end{array}$ \\
\hline rqump00 & 0.062 & 0.152 & 0.236 & 0.169 & 0.113 & 0.092 & 0 & 0.171 \\
\hline rqump01 & 0.075 & 0.15 & 0.227 & 0.184 & 0.104 & 0.083 & 0 & 0.173 \\
\hline rqump02 & 0.074 & 0.15 & 0.251 & 0.160 & 0.102 & 0.080 & 0 & 0.180 \\
\hline rqump03 & 0.074 & 0.153 & 0.231 & 0.173 & 0.114 & 0.091 & 0 & 0.160 \\
\hline rqump04 & 0.071 & 0.145 & 0.193 & 0.168 & 0.135 & 0.026 & 0.083 & 0.175 \\
\hline rqump05 & 0.064 & 0.149 & 0.179 & 0.157 & 0.127 & 0.039 & 0.093 & 0.187 \\
\hline rqump06 & 0.061 & 0.154 & 0.216 & 0.167 & 0.131 & 0.076 & 0 & 0.192 \\
\hline rqump07 & 0.068 & 0.15 & 0.196 & 0.154 & 0.126 & 0.027 & 0.086 & 0.190 \\
\hline rqump08 & 0.062 & 0.156 & 0.209 & 0.153 & 0.131 & 0.098 & 0 & 0.188 \\
\hline rqump09 & 0.062 & 0.168 & 0.208 & 0.178 & 0.120 & 0.092 & 0 & 0.169 \\
\hline rqump10 & 0.075 & 0.270 & 0.267 & 0 & 0.130 & 0.121 & 0 & 0.134 \\
\hline rqump11 & 0.061 & 0.152 & 0.202 & 0.171 & 0.136 & 0.092 & 0 & 0.183 \\
\hline rqump12 & 0.062 & 0.238 & 0.175 & 0.115 & 0 & 0.128 & 0 & 0.280 \\
\hline rqump13 & 0.091 & 0.261 & 0.300 & 0 & 0.171 & 0.035 & 0.138 & 0 \\
\hline rqump14 & 0.063 & 0.264 & 0.263 & 0 & 0.100 & 0.099 & 0 & 0.209 \\
\hline rqump15 & 0.062 & 0.148 & 0.202 & 0.160 & 0.132 & 0.025 & 0.085 & 0.183 \\
\hline rqump16 & 0.069 & 0.240 & 0.190 & 0.115 & 0 & 0.101 & 0 & 0.282 \\
\hline Mean & 0.068 & 0.182 & 0.220 & 0.130 & 0.110 & 0.076 & 0.028 & 0.179 \\
\hline Standard deviation & 0.008 & 0.048 & 0.034 & 0.065 & 0.044 & 0.033 & 0.047 & 0.059 \\
\hline
\end{tabular}

to the Tibetan Plateau in the reanalyses being assigned to the Karakoram/Hindu Kush in the model ensemble. Future work will investigate differences in climatology between reanalysis zones (as presented in Sect. 3.2 and Figs. 6 and 7) and the model ensemble zones. This analysis will then be extended to compare climate classifications between time slices of the model ensemble.

In summary, the climate classification approach presented here has substantial potential for use in assessment of water resources and food security issues as well as for the characterisation of skill and bias of gridded data sets for reproducing subregional climatologies. This relative, or internaldifference, classification approach was preferred over a methodology based on fixed, absolute thresholds due to the nature of the gridded data sets, whose spatial discretisation on likely intrinsic biases would distort the results of an absolutist method. The natural resource assessment application of this approach is timely, as increasing pressures on water resources and cropland appear inevitable in South Asia for the medium term due to demographic trends and evolving consumption patterns. The growing availability of gridded data sets increases the likelihood of their use to address resource management and climatic sensitivity issues. In order to use these data sets skilfully it is necessary to first rigorously characterise their performance and biases. Thus the climate classification approach presented here is doubly timely as it provides a framework to organise use of in situ observations to differentiate gridded data set performance at the subregional level and to carry out inter-comparison of gridded data set performance for these subregions.

\section{Conclusions}

A three-step approach was used to derive climate classifications for the Himalayan arc and adjacent plains from climate inputs from four global meteorological reanalyses covering the recent historical record (1980 to 2009). Input variables were selected for this process with a focus on climatic drivers of water resources and agricultural production. Knowledge of the climatic factors governing behaviour of hydrological regimes with substantial contributions from seasonal snowpack and glaciers as well as controlling crop growth led to selection of precipitation amount, daily mean temperature, net shortwave radiation at the surface and DTR as input variables. Three seasonal aggregations were chosen for each input variable. Annual, "rabi" (October to March) and "kharif" (April to September) totals were used for precipitation to differentiate the influences of westerly mid-latitude and monsoonal sub-tropical weather systems. For the remaining variables temporal aggregates for winter (December to February), spring (March to May) and summer (June to August) were selected to identify hydrological regimes - pluvial, nival (snowpack) or glacial - and growing seasons dependent upon thermal conditions.

Principal component analysis (PCA) was applied to the spatially standardised temporal aggregates of the input vari- 
Table 6. Comparison of RQUMP perturbed physics ensemble climate model subregional climate zone distributions to those from the reanalysis ensemble.

\begin{tabular}{|c|c|c|c|c|c|c|c|c|c|}
\hline \multicolumn{2}{|c|}{ Statistic } & $\begin{array}{l}\text { Indian } \\
\text { Ocean }\end{array}$ & $\begin{array}{r}\text { Central } \\
\text { Asian } \\
\text { deserts }\end{array}$ & $\begin{array}{r}\text { Gangetic } \\
\text { plains }\end{array}$ & $\begin{array}{r}\text { Lower } \\
\text { Indus } \\
\text { Basin }\end{array}$ & $\begin{array}{r}\text { Karakoram/ } \\
\text { Hindu } \\
\text { Kush }\end{array}$ & $\begin{array}{r}\text { Himalayan } \\
\text { arc }\end{array}$ & $\begin{array}{r}\text { Ganges- } \\
\text { Brahmaputra } \\
\text { Delta }\end{array}$ & $\begin{array}{l}\text { Tibetan } \\
\text { Plateau }\end{array}$ \\
\hline \multirow{3}{*}{$\begin{array}{l}\text { Ensemble } \\
\text { means }\end{array}$} & Climate model & 0.068 & 0.182 & 0.220 & 0.130 & 0.110 & 0.076 & 0.028 & 0.179 \\
\hline & Reanalyses & 0.073 & 0.154 & 0.198 & 0.164 & 0.059 & 0.050 & 0.089 & 0.232 \\
\hline & Difference & -0.005 & 0.028 & 0.022 & -0.034 & 0.051 & 0.026 & -0.061 & -0.053 \\
\hline \multirow{3}{*}{$\begin{array}{l}\text { Ensemble } \\
\text { standard } \\
\text { deviations }\end{array}$} & Climate model & 0.008 & 0.048 & 0.034 & 0.065 & 0.044 & 0.033 & 0.047 & 0.059 \\
\hline & Reanalyses & 0.006 & 0.041 & 0.027 & 0.027 & 0.006 & 0.015 & 0.014 & 0.024 \\
\hline & Difference & 0.002 & 0.007 & 0.007 & 0.038 & 0.038 & 0.018 & 0.033 & 0.035 \\
\hline
\end{tabular}

ables. Comparison of PCA results from the four reanalyses shows that in all cases the first principal component was dominated by energy inputs, while the second and third were dominated by precipitation and DTR. Principal components accounting for a minimum of $5 \%$ of total input variance, supplemented with standardised latitude and longitude, were used as inputs to a $k$-means cluster analysis. Progressive increases in cluster numbers were tested for each reanalysis in order to assess the evolution of emergent climate zones. Results of the $k$-means analysis were interpreted to show that the study domain could be adequately described by eight subregional climate classifications, while further increases in cluster numbers resulted in subdivisions of these macrozones. Spatial statistics for each subregional climate zone from the ensemble of reanalyses revealed consistent, distinct climatologies in the annual cycles of the input variables.

The capacity of the climate classifications to provide insight into water resources and food security issues at a regional scale was discussed. This capacity is linked to the objective delineation of water resource supply and demand zones. Analysis of changes in both the spatial and climatic characteristics of the zones over time provides a framework for evaluation of water availability for crop production. The climate classifications also support evaluation of gridded data sets themselves. The climate zones provide an objective method for grouping available ground-based observations to quantify and summarise gridded data set bias. They also serve as a metric with which to compare climatologies of gridded data sets. This was illustrated by comparing the climate classifications of the ensemble of reanalyses to the "control period" of a dynamically downscaled perturbed physics climate model ensemble. Strong commonalities between the benchmark (reanalysis) and predictive (RCM) data sets were evident while limited divergences were clearly identified. Future work will extend the methodology here to evaluate the regional water resources and food security implications of changes projected by available RCM experiments covering South Asia and the Himalayan arc.
Acknowledgements. This study was made possible by financial support from the Leverhulme Trust via a Philip Leverhulme Prize (2011) awarded to H. J . Fowler. Local meteorological data were acquired from the Pakistan Meteorological Department (PMD) with support from the Global Change Impact Studies Centre (GCISC). Additional financial support during the developmental stages of this work was provided by the British Council (PMI2 and INSPIRE grants), the UK Natural Environment Research Council (NERC) through a postdoctoral fellowship award NE/D009588/1 (2006-2010) to H. J . Fowler, and the US National Science Foundation (NSF) through a graduate research fellowship award to N. Forsythe (2006-2010). H. J. Fowler is funded by the Wolfson Foundation and the Royal Society as a Royal Society Wolfson Research Merit Award (WM140025) holder.

Edited by: V. Lucarini

\section{References}

Archer, D. R.: Contrasting hydrological regimes in the Indus Basin, J. Hydrol., 274, 198-210. doi:10.1016/S0022-1694(02)00414-6, 2003.

Archer, D. R.: Hydrological implications of spatial and altitudinal variation in temperature in the Upper Indus Basin, Nord. Hydrol., 35, 209-222, 2004.

Archer, D. R. and Fowler, H. J.: Spatial and temporal variations in precipitation in the Upper Indus Basin, global teleconnections and hydrological implications, Hydrol. Earth Syst. Sci., 8, 47-61, doi:10.5194/hess-8-47-2004, 2004.

Archer, D. R. and Fowler, H. J.: Using meteorological data to forecast seasonal runoff on the River Jhelum, Pakistan, J. Hydrol., 361, 10-23, doi:10.1016/j.jhydrol.2008.07.017, 2008.

Archer, D. R., Forsythe, N., Fowler, H. J., and Shah, S. M.: Sustainability of water resources management in the Indus Basin under changing climatic and socio economic conditions, Hydrol. Earth Syst. Sci., 14, 1669-1680, doi:10.5194/hess-14-16692010, 2010.

Baigorria, G. A., Jones, J. W., Shin, D.-W., Mishra, A., and O'Brien, J. J.: Assessing uncertainties in crop model simulations using daily bias-corrected Regional Circulation Model outputs, Clim. Res., 34, 211-222, doi:10.3354/cr00703, 2007. 
Belda, M., Holtanová, E., Halenka, T., and Kalvová, J.: Climate classification revisited: From Köppen to Trewartha, Clim. Res., 59 1-13, doi:10.3354/cr01204, 2014.

Bhaskaran, B., Ramachandran, A., Jones, R., and MoufoumaOkia, W.: Regional climate model applications on sub-regional scales over the Indian monsoon region: The role of domain size on downscaling uncertainty, J. Geophys. Res.-Atmos., 117, D10113, doi:10.1029/2012JD017956, 2012.

Blenkinsop, S., Fowler, H. J., Dubus, I. G., Nolan, B. T., and Hollis, J. M.: Developing climatic scenarios for pesticide fate modelling in Europe, Environ. Pollut., 154, 219-231, doi:10.1016/j.envpol.2007.10.021, 2008.

Chen, D. and Chen, H. W.: Using the Köppen classification to quantify climate variation and change: An example for 1901-2010, Environ. Develop., 6, 69-79, doi:10.1016/j.envdev.2013.03.007, 2013.

Collins, M., Booth, B. B. B., Bhaskaran, B., Harris, G. R., Murphy, J. M., Sexton, D. M. H., and Webb, M. J.: Climate model errors, feedbacks and forcings: a comparison of perturbed physics and multi-model ensembles, Clim. Dynam., 36, 1737-1766, doi:10.1007/s00382-010-0808-0, 2011.

Dee, D. P., Uppala, S. M., Simmons, A. J., Berrisford, P., Poli, P., Kobayashi, S., Andrae, U., Balmaseda, M. A., Balsamo, G., Bauer, P., Bechtold, P., Beljaars, A. C. M., van de Berg, L., Bidlot, J., Bormann, N., Delsol, C., Dragani, R., Fuentes, M., Geer, A. J., Haimberger, L., Healy, S. B., Hersbach, H., Holm, E. V., Isaksen, L., Kallberg, P., Kohler, M., Matricardi, M., McNally, A. P., Monge-Sanz, B. M., Morcrette, J.-J., Park, B.-K., Peubey, C., de Rosnay, P., Tavolato, C., Thepaut, J.-N., and Vitart, F.: The ERA-Interim reanalysis: configuration and performance of the data assimilation system, Q. J. R. Meteorol. Soc., 137, 553-597, doi:10.1002/qj.828, 2011.

de Fraiture, C. and Wichelns, D.: Satisfying future water demands for agriculture, Agr. Water Manage., 97, 502-511, doi:10.1016/j.agwat.2009.08.008, 2010.

Easterling, D. R., Horton, B., Jones, P. D., Peterson, T. C., Karl, T. R., Parker, D. E., Salinger, M. J., Razuvayev, V., Plummer, N., Jamason, P., and Folland, C. K.: Maximum and minimum temperature trends for the globe, Science, 277, 364-367, doi:10.1126/science.277.5324.364, 1997.

Ebita, A., Kobayashi, S., Ota, Y., Moriya, M., Kumabe, R., Onogi, K., Harada, Y., Yasui, S., Miyaoka, K., Takahashi, K., Kamahori, H., Kobayashi, C., Endo, H., Soma, M., Oikawa, Y., and Ishimizu, T.: The Japanese 55-year Reanalysis "JRA-55": An Interim Report, Scientific Online Letters on the Atmosphere, 7, 149-152, doi:10.2151/sola.2011-038, 2011.

Elguindi, N., Grundstein, A., Bernardes, S., Turuncoglu, U., and Feddema, J.: Assessment of CMIP5 global model simulations and climate change projections for the 21 st century using a modified Thornthwaite climate classification, Clim. Change, 122, 523-538, doi:10.1007/s10584-013-1020-0, 2014.

Holderness, T.: Python Spatial Image Processing (PyRaster), available at: https://github.com/talltom/PyRaster (last access: $1 \mathrm{Au}$ gust 2014), 2011.

Hunter, J. D.: Matplotlib: A 2D graphics environment, Comput. Sci. Eng., 9, 90-95, doi:10.1109/MCSE.2007.55, 2007.

Immerzeel, W. W. and Bierkens, M. F. P.: Asia's water balance, Nat. Geosci., 5, 841-842, doi:10.1038/ngeo1643, 2012.
Immerzeel, W. W., Van Beek, L. P. H., and Bierkens, M. F. P.: Climate change will affect the Asian water towers, Science, 328, 1382-1385, doi:10.1126/science.1183188, 2010.

Immerzeel, W. W., Pelicciotti, F., and Shrestha, A. B.: Glaciers as a Proxy to Quantify the Spatial Distribution of Precipitation in the Hunza Basin, Mount. Res. Develop., 32, 30-38, doi:10.1659/MRD-JOURNAL-D-11-00097.1, 2012.

Kar, G., Kumar, A., Sahoo, N., and Mohapatra, S.: Radiation utilization efficiency, latent heat flux, and crop growth simulation in irrigated rice during post-flood period in east coast of India, Paddy Water Environ., 12, 285-297, doi:10.1007/s10333-013-0381-3, 2014.

Khan, S. I., Hong, Y., Gourley, J. J., Khan Khattak, M. U., Yong, B., and Vergara, H. J.: Evaluation of three highresolution satellite precipitation estimates: Potential for monsoon monitoring over Pakistan, Adv. Space Res., 54, 670-684, doi:10.1016/j.asr.2014.04.017, 2014.

Lawrimore, J. H., Menne, M. J., Gleason, B. E., Williams, C. N., Wuertz, D. B., Vose, R. S., and Rennie, J.: An overview of the Global Historical Climatology Network monthly mean temperature data set, version 3, J. Geophys. Res., 116, D19121, doi:10.1029/2011JD016187, 2011.

Mahlstein, I., Daniel, J. S., and Solomon, S.: Pace of shifts in climate regions increases with global temperature, Nat. Clim. Change, 3, 739-743, doi:10.1038/nclimate1876, 2013.

Nolan, B. T., Dubus, I. G., Surdyk, N., Fowler, H. J., Burton, A., Hollis, J. M., Reichenberger, S., and Jarvis, N. J.: Identification of key climatic factors regulating the transport of pesticides in leaching and to tile drains, Pest Manage. Sci., 64, 933-944, doi:10.1002/ps.1587, 2008.

Ragettli, S., Pellicciotti, F., Bordoy, R., and Immerzeel, W. W.: Sources of uncertainty in modeling the glaciohydrological response of a Karakoram watershed to climate change, Water Resour. Res., 49, 6048-6066, doi:10.1002/wrcr.20450, 2013.

Rienecker, M. M., Suarez, M. J., Gelaro, R., Todling, R., Bacmeister, J., Liu, E., Bosilovich, M. G., Schubert, S. D., Takacs, L., Kim, G.-K., Bloom, S., Chen, J., Collins, D., Conaty, A., Da Silva, A., Gu, W., Joiner, J., Koster, R. D., Lucchesi, R., Molod, A., Owens, T., Pawson, S., Pegion, P., Redder, C. R., Reichle, R., Robertson, F. R., Ruddick, A. G., Sienkiewicz, M., and Woollen, J.: MERRA: NASA's modern-era retrospective analysis for research and applications, J. Climate, 24, 3624-3648, doi:10.1175/JCLI-D-11-00015.1, 2011.

Saha, S., Moorthi, S., Pan, H.-L., Wu, X., Wang, J., Nadiga, S., Tripp, P., Kistler, R., Woollen, J., Behringer, D., Liu, H., Stokes, D., Grumbine, R., Gayno, G., Wang, J., Hou, Y.-T., Chuang, H.Y., Juang, H.-M. H., Sela, J., Iredell, M., Treadon, R., Kleist, D., Van Delst, P., Keyser, D., Derber, J., Ek, M., Meng, J., Wei, H., Yang, R., Lord, S., Van Den Dool, H., Kumar, A., Wang, W., Long, C., Chelliah, M., Xue, Y., Huang, B., Schemm, J.-K., Ebisuzaki, W., Lin, R., Xie, P., Chen, M., Zhou, S., Higgins, W., Zou, C.-Z., Liu, Q., Chen, Y., Han, Y., Cucurull, L., Reynolds, R. W., Rutledge, G., and Goldberg, M.: The NCEP climate forecast system reanalysis, B. Am. Meteorol. Soc., 91, 1015-1057, doi:10.1175/2010BAMS3001.1, 2011.

Siebert, S., Döll, P., Feick, S., Hoogeveen, J., and Frenken, K.: The digital global map of irrigation areas (version 4.5). Food and Agriculture Organization of the United Nations, Rome, Italy, 
available at: http://www.fao.org/nr/water/aquastat/irrigationmap/ index10.stm, 2007.

Uppala, S. M., Kallberg, P. W., Simmons, A. J., Andrae, U., Da Costa Bechtold, V., Fiorino, M., Gibson, J. K., Haseler, J., Hernandez, A., Kelly, G. A., Li, X., Onogi, K., Saarinen, S., Sokka, N., Allan, R. P., Andersson, E., Arpe, K., Balmaseda, M. A., Beljaars, A. C. M., Vande Berg, L., Bidlot, J., Bormann, N., Caires, S., Chevallier, F., Dethof, A., Dragosavac, M., Fisher, M., Fuentes, M., Hagemann, S., Holm, E., Hoskins, B. J., Isaksen, L., Janssen, P. A. E. M., Jenne, R., McNally, A. P., Mahfouf, J.-F., Morcrette, J.-J., Rayner, N. A., Saunders, R. W., Simon, P., Sterl, A., Trenberth, K. E., Untch, A., Vasiljevic, D., Viterbo, P., and Woollen, J.: The ERA-40 re-analysis, Q. J. Roy. Meteorol. Soc., 131, 2961-3012, doi:10.1256/qj.04.176, 2005.
Zhang, X. and Yan, X.: Spatiotemporal change in geographical distribution of global climate types in the context of climate warming, Clim. Dynam., 43, 595-605, doi:10.1007/s00382-013-2019y, 2014. 